\title{
O que é uma aula? Análises sociológicas sobre a construção de uma atividade do trabalho docente.
}

\author{
What is a class? Sociological analysis on the construction of a teaching work \\ activity.
}

\section{¿Qué es una clase? Análisis sociológicos sobre la construcción de una actividad del trabajo docente.}

\begin{abstract}
Resumo: Este artigo é o resultado de leituras e discussões realizadas em uma turma de graduação composta por diferentes estudantes de diversos cursos de licenciaturas em uma Instituição Federal de Ensino Superior (IFES). O material tem por objetivo apresentar reflexões sobre o conceito de aula como uma categoria particular de atividade do trabalho docente em espaços formais e regulares de ensino. A compreensão e a fundamentação das análises apresentadas encontram-se vinculadas teoricamente aos campos da Sociologia da Educação e da Formação de Docente, sobretudo na intersecção desses dois campos a partir da configuração de uma Sociologia da Formação e da Profissão Docente. Trata-se especificamente de uma interpretação das variantes do conceito de aula à luz da especificidade dos condicionamentos culturais, históricos e sociais experimentados no contexto do exercício do magistério em um procedimento metodológico do tipo de experiência da pesquisa-ação. $O$ argumento central do texto é o de que, como um conceito, a aula representa uma atividade do trabalho docente que guarda um estoque diverso de significados.
\end{abstract}

Palavras-chave: Aula. Sociologia da Educação. Formação Docente. Sociologia da Formação e da Profissão Docente.

Abstract: This article is the result of readings and discussions held in a graduate university education composed of different students from several undergraduate courses at a Federal Institution of Higher Education (FIHE). The aim of the material is to present reflections on the concept of class as a particular category of teaching work activity in formal and regular teaching spaces. The understanding and the rationale of the analyzes presented are theoretically linked to the fields of Sociology of Education and Teacher Training, especially in the intersection of these two fields from the configuration of a Sociology of Formation and Teaching Profession. It is specifically an interpretation of the variants of the concept of class in the light of the specificity of cultural, historical and social conditions experienced in the context of the exercise of teaching in a methodological procedure of the type of action research experience. The central argument of the text is that, as a concept, the class represents an activity of the teaching work that holds a diverse stock of meanings.

Keywords: Class. Sociology of Education. Teacher Training. Sociology of Formation and Teaching Profession.

1 Historiador (PUC-Minas) e Pedagogo (UFMG). Mestre e Doutor em Educação (UFMG). Professor do Departamento de Ciências Aplicadas à Educação (DECAE/Setor de Sociologia da Educação), na Faculdade de Educação da Universidade Federal de Minas Gerais (FaE/UFMG).

E-mail: fredasc@gmail.com 
Resumen: Este artículo es el resultado de lecturas y discusiones realizadas en un grado de graduación compuesta por diferentes estudiantes de diversos cursos de licenciaturas en una Institución Federal de Enseñanza Superior (IFES). El material tiene por objetivo presentar reflexiones sobre el concepto de clase como una categoría particular de actividad del trabajo docente en espacios formales y regulares de enseñanza. La comprensión y la fundamentación de los análisis presentados se encuentran vinculadas teóricamente a los campos de la Sociología de la Educación y de la Formación de Docente, sobre todo en la intersección de estos dos campos a partir de la configuración de una Sociología de la Formación y de la Profesión Docente. Se trata específicamente de una interpretación de las variantes del concepto de clase a la luz de la especificidad de los condicionamientos culturales, históricos y sociales experimentados en el contexto del ejercicio del magisterio en un procedimiento metodológico del tipo de experiencia de la investigación-acción. El argumento central del texto es que, como un concepto, la clase representa una actividad del trabajo docente que guarda un stock diverso de significados.

Palabras clave: Clase. Sociología de la Educación. Formación docente. Sociología de la Formación y de la Profesión Docente.

\section{INTRODUÇÃO: O QUE É UMA AULA?}

Em 2017 eu lecionava para uma turma composta majoritariamente por jovens graduandos $/ a^{2}$ de diferentes cursos de licenciaturas. Depois da segunda aula do semestre, um estudante do Curso de Física me aguardou no corredor da Faculdade enquanto eu juntava os meus materiais para ir embora. O rapaz, de 25 anos de idade, havia mudado recentemente a sua trajetória de formação, do bacharelado para a licenciatura. Estimulado por seus professores do curso de origem, notadamente homens, que argumentavam não enxergar nele um promissor pesquisador da área de Física. Depois de narrar os seus conflitos de universitário, o jovem revelou que aquele era o seu primeiro semestre na Faculdade de Educação. Ele cursava a disciplina de Psicologia da Educação e estava matriculado no componente curricular sob a minha responsabilidade: Sociologia da Educação. Apenas no semestre letivo seguinte ele cursaria as disciplinas de Didática e de Política Educacional. Essas quatro disciplinas, obrigatórias para a formação de futuros/as professores/as, configuram a única opção de disciplinas obrigatórias para licenciandos/as na Faculdade.

A conversa já tomava rumos para terminar quando o jovem me confidenciou sua dúvida: “- Professor, afinal, o que é uma aula?". A pergunta do estudante não faria sentido se na verdade ele e boa parte das pessoas na contemporaneidade fossem, ou já tivessem sido, alunos/as ou estudantes ${ }^{3}$. Ocorre que a após de democratização da educação, da obrigatoriedade do ensino regular formal para as massas, a noção de aula poderia ser

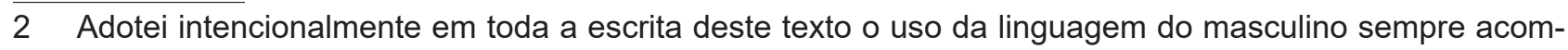
panhada do feminino quando me refiro tanto a homens como a mulheres. Com a escolha viso fugir das armadilhas dos processos discursivos e linguísticos que tentam hierarquizar as diferenças entre as pessoas. Mais que uma questão semântica, esta é uma opção política.

3 No idioma francês as nomenclaturas alunos/as e estudantes servem para diferenciar tanto os estados de formação como a faixa etária dos sujeitos. Embora na língua portuguesa as expressões sejam usadas 
compreendida como um denominador cultural relativamente comum do nosso tempo. Dada certa banalização da ideia de aula, por conhecimento de efetiva prática, como aluno/a ou estudante, a questão poderia se enquadrar em uma lógica de conceito de significância; significado sobre o qual o conceito se explica por si só. Um entendimento, de certa forma, quase tautológico. No entanto, a questão proposta na forma de uma indagação não demandava uma resposta assertiva baseada na experiência pessoal de milhares de pessoas de todo o mundo no cotidiano. O jovem refez, então, a sua pergunta inicial: "- Digo, o que é uma aula, teoricamente?".

As aulas, para além das experiências escolares contemporâneas que atravessam as pessoas, já foram contadas em verso e prosa; tendo sido objeto de filmes ${ }^{4}$, de romances literários ${ }^{5}$, de dossiês analíticos ou descritivos produzidos por acadêmicos/as e/ou técnicos/ as. Enquanto um conceito, o termo tendo sido utilizado a partir de diferentes definições e diversos métodos de análise ao longo dos últimos décadas, interessando, sobretudo, o campo dos "Ensinos de"6. Então, como não saber o que é uma aula? Ou, como saber o que é uma aula? O que a define? O que a explica?

como sinônimos, mantenho a lógica francofônica conhecida no campo da Sociologia da Educação para a qual o termo alunos/as (ou "les élèves") refere-se às crianças e aos/às adolescentes da educação básica enquanto estudantes (ou "les étudiante/étudiants", na forma feminino/masculino) refere-se aos/às jovens e adultos/as matriculados/as no ensino superior. Também por opção adoto o termo professores/as para me referir tanto aos/às docentes da educação básica como os/as do ensino superior, ainda que a profissão também seja diferente na língua francesa ("les éducatrices/éducateurs", educadoras ou educadores, respectivamente, para o trabalho na educação infantil, ou "les enseignantes/enseignants", ensinantes, termos usados para definir docentes da educação básica e "les professerures/professeurs", professores e professoras, para o ensino superior), não havendo tradução diferente específica para as duas categorias profissionais na língua portuguesa.

4 O cinema produziu ao longo de muitos anos diversas representações de escola e de seus sujeitos, bem como variedades distintas de representações sobre o que seria uma aula. As representações, produtos e produtoras de arquétipos sobre a educação, narraram, muitas vezes, representações ingênuas e reducionistas do ato pedagógico. Endereçadas ao público mais amplo, as produções retrataram as agruras do sistema de ensino sendo superadas pela força de personagens benfazejas que lutavam contra opressões culturais, econômicas ou sociais. Essa narrativa construiu heróis e heroínas que responderam aos interesses prosaicos e imediatos dos/as expectadores/as. Cf. filmes como "Ao mestre, com carinho" (1967); "Meu mestre, minha vida" (1989); "Sociedade dos poetas mortos" (1989); "Um tira no jardim de infância" (1990); "Mr. Holland: adorável professor" (1995); "O sorriso de Mona Lisa (2003) e "Escritores da liberdade" (2007). Apesar das diferenças entre temáticas e tipologias de gêneros, essas obras guardam como caraterística geral a fabricação de discursos caricatos sobre a complexidade do ato educativo.

5 O que na crítica literária convencionou-se nomear por Bildungsroman, termo em alemão relativo aos romances de formação e cuja obra principal talvez seja "Os anos de aprendizado de Wilhelm Meister", de autoria de Johann Wolfgang von Goethe Cf. Goethe (1994); Cardoso (2013).

6 Refiro-me, sobretudo, aos trabalhos no campo da Didática do Ensino (de ciências, de história, de geografia etc.) estando a questão também presente na formação de docentes para a Educação Infantil e a Educação de Jovens e de Adultos. Questões como métodos de alfabetização e de letramento, tipologias de avaliação e organização e planejamento do ensino têm como pano de fundo a aula. Cf. Callai (2005); Camargo e Zamboni (1988); Viana (2014) e Zamboni e Fonseca (2010). 
As perguntas daquele jovem permaneceram comigo e a provocativa questão foi socializada em sala logo na aula seguinte. Assim, todo o planejamento do semestre foi revisto para tentar respondermos coletivamente, eu e os/as estudantes, àquele enunciado. Dessa maneira passei a trabalhar conceitos específicos do campo da Sociologia da Formação e da Profissão de Docente ${ }^{7}$. Depois de uma apresentação panorâmica sobre a literatura clássica, cuja mirada alargada serviu para apresentar o campo da Sociologia da Educação, passei a investir no recorte de escolhas de estudos que analisassem prioritariamente os sujeitos da educação ${ }^{8}$, professores/as e alunos/as, e sua relação com a instituição escolar, tendo como foco a aula.

Este artigo nasce da provocação para responder o que seria teoricamente uma aula, fruto de uma reflexão de minha própria prática docente em uma Faculdade de Educação em conjunto com as descobertas de meus/minhas estudantes ${ }^{9}$. O texto busca comunicar um determinado conceito de aula, firmando-o no campo da Educação e, mais especificamente, no campo de uma Sociologia da Formação e da Profissão Docente. Para além da curiosa compreensão do que seria uma aula espero que o texto possa se tornar cientificamente útil para pesquisadores/as em Educação e profissionais do ensino que já dominam seu léxico e igualmente benéfico para iniciantes em formação no campo da Educação. Para capturar

7 Considero como Sociologia da Formação e da Profissão Docente o campo de investimentos de pesquisa que une duas chaves de leituras teóricas: de um lado a Sociologia da Educação e os interesses na formação profissional de professores/as e, de outro, o campo dos estudos sobre a Profissão Docente. De maneira geral a literatura especializada no campo dos estudos de uma Sociologia da Formação e da Profissão Docente indica que os indivíduos desenvolvem seu processo de formação profissional assumindo a construção identitária de diversas atitudes e de diferentes valores. Os estudos tendem a indicar que a formação do/a professor/a se processa ao longo de toda a sua vida pessoal e profissional, em tempos e espaços formativos diversos. Compõem um quadro teórico e analítico os estudos sobre o/a professor/a e a sua formação (TARDIF; LESSARD, 2014a e 2014b); a construção de sua identidade (CONTRERAS, 2002; DUBAR, 2005 e PIMENTA, 1999); seus saberes (CHARLOT, 2000; LIBÂNEO, 2002; TARDIF, 2014 e TARDIF, 2000), experiências (BONDÍA, 2002) e ainda suas práticas e reflexões (NÓVOA, 1999; PIMENTA; GHEDIN, 2008 e SCHÖN, 2008).

8 Foi assim que a disciplina de 60h/a foi dividida em quatro unidades de 15h/a cada. Na primeira unidade, Educação, escola e cultura: bases sociais e epistemológicas do conhecimento escolar (I), foram estudados os "clássicos" fundadores da sociologia, priorizando leituras de fontes primárias de Durkheim, Marx e Weber. Nas três unidades seguintes, Desigualdades sociais e desigualdades escolares: abordagens sociológicas e análises gerais sobre os temas (II); Sociologia da Educação: temas contemporâneos (III) e; A sociologia interroga a escola: as bases de uma sociologia da formação e da profissão docente (IV), o conceito de "aula" foi estudado de maneira transversal. De toda forma, a alteração do plano de ensino respeitou a ementa e os objetivos definidos pela Faculdade para o componente curricular.

9 Mais do que um texto destinado para estudantes licenciandos/as, o artigo objetiva ser a comunicação de um resultado de conversas com estudantes. Em tal perspectiva metodológica estiveram implicados o professor e a sua turma, motivados/as por um interesse comum de análise sociológica. Em outros termos, um exercício de realização de uma socioanálise em situação de aprendizagem formativa, buscando romper com o silêncio habitual sobre as condições e as práticas de investigações científicas mais conservadoras. 
a variedade de compreensões que invocam o conceito, a estrutura do texto foi construída na forma de uma abordagem teórico-analítica, entre tantas outras possíveis, orientada por uma abordagem intersubjetiva e microssociológica dos fenômenos educacionais. Uma Sociologia mais imaginativa, nos termos de Mills (1969), ou uma Sociologia em que:

Diante das transformações contemporâneas das sociedades ocidentais, metáforas, imagens e novos conceitos floresceram na linguagem sociológica para tentar descrever a natureza do mundo em que vivemos e como ele se difere do que conhecemos até agora. (MOLÉNAT, 2009, p. 172, tradução minha).

Resultado de um tipo de pesquisa-ação, esta comunicação está alicerçada sobre dois elementos relevantes no processo coletivo de investigação: a convivência e a participação. Tais componentes já indicam o seu "distanciamento dos cânones da concepção clássica, tradicional de ciência, na qual esta constitui um conjunto de conhecimentos comprovados e objetivos produzidos por métodos rigorosos e supostamente neutros" (COSTA, 2007, p. 93).

\section{DESVENDANDO A "CAIXA-PRETA": A HISTÓRIA DA AULA, A AULA COMO UMA ATIVIDADE DO TRABALHO DOCENTE E O MITO DA NEUTRALIDADE PEDAGÓGICA}

Talvez seja possível afirmar que qualquer pessoa tenha algo a dizer sobre o que é uma aula. Compreendida como o encontro de pessoas em um momento de formação ela ocorre em espaços e em contextos diversos: em salas de escolas e de universidades, em atividades físicas ou recreativas, em cursos de treinamentos empresariais, na forma de espaços virtuais de aprendizagem, em laboratórios, em oficinas profissionais ou mesmo em igrejas, se considerado o estudo das escrituras por parte de diferentes religiões em círculos de estudo e "escolas dominicais". No entanto, uma parcela do que as pessoas sabem sobre o que é uma aula, como elas constroem seus modelos de pensamento e de significação sobre uma aula, tem como ponto comum a escola. Como instituição que atravessa as pessoas, uma instituição quase total, a cultura escolar e a cultura da escola ${ }^{10}$ antecedem e ultrapassam as experiências pessoais dos indivíduos no mundo contemporâneo. É assim que

10 Entende-se por cultura escolar os aspectos da vida social inaugurados pela e na escola. Trata-se de um conjunto de comportamentos, de modelos e de práticas pedagógicas destinado à transmissão de diferentes conteúdos e normas sociais realizada no ambiente escolar. Via de regra a cultura escolar não proporciona apenas o aprendizado da relação do sujeito com a língua, por exemplo, mas sobretudo o aprendizado de um modo específico de relação do sujeito com a língua. Talvez o uso da língua seja, entre as práticas culturais, a forma socialmente mais rentável de existência. Um domínio mínimo qualquer da língua é diferente do domínio da linguagem na forma escolar, e isso constitui o conjunto de bases da cultura escolar. A forma como alunos/as e estudantes lidam com a língua talvez seja a única prática eficaz que mobiliza as competências valorizadas pela e na escola. Ou seja: a cultura escolar destina-se à forma de pensar criticamente, de falar e de escrever "elegantemente", segundo padrões arbitrários da norma "cultura" do idioma de origem. Já a cultura da escola refere-se mais à uma sociologia do estabele- 
no momento em que redigia este texto milhares de pessoas ao redor da Terra vivenciavam experiências com uma aula: se deslocavam para uma aprendizagem formativa, estudavam, preparavam seus materiais; professores/as planejavam, ministravam ou corrigiam as atividades avaliativas de seus/suas alunos/as ou estudantes em culturas tão diferentes entre si como a escolarização dos/as chineses/as e a escolarização da população sul-americana ${ }^{11}$.

Por estar presente na vida de pessoas tão diferentes, uma aula pode ser muita coisa. Uma definição de senso comum mais óbvia sugeriria que a aula dependeria do contexto histórico e que sua concepção também dependeria daquilo que em determinado tempo determinada cultura de determinada sociedade compreenderia, desejaria e definiria por aula. Essa premissa básica fornece uma ilustração razoavelmente interessante de como o conceito se espalha pelo campo da Educação ao longo do tempo e em diferentes espaços, de toda forma, espaços geográficos e sociais.

Ainda que seja possível afirmar que a aula varia no tempo e no espaço, tal premissa parece não responder à questão: o que seria, teoricamente, uma aula? No campo da Sociologia da Educação talvez a aula ainda possa ser representada como um microcosmos sobre o qual pouco sabemos com consistência, uma espécie de "caixa-preta", nos termos de Sirota (1994). Aquilo que, parecendo escapar de aspectos que não sejam já bastante familiares, mereceria mais investigação. Obviamente estudos mais recentes, em diferentes campos da Educação, sobretudo no campo do currículo ${ }^{12}$ e no campo dos estudos nos/dos/

cimento de ensino. Voltada para aspectos organizacionais, a cultura da escola representa o ethos de um estabelecimento, a relativa autonomia de seu projeto pedagógico e suas diretrizes educativas, como por exemplo, os calendários, as condutas, os costumes, as crenças, os hábitos, as ideologias, as normas, os projetos, as regras, as rotinas, os rituais e os valores, entre outros aspectos, que variam de educandário para educandário e que ajudam a configurar um determinado tipo de escola. Cf. Barroso (2012).

11 Curiosamente, no momento em que fazia a última revisão deste artigo para a sua publicação, a experiência do que conhecemos sobre o que é uma aula estava sendo atravessada pela pandemia mundial provocada pelo novo coronavírus. Esse momento específico forçou novas configurações sobre os modelos de aula, fazendo com que docentes de todo o mundo passassem a desenvolver atividades de teletrabalho. Apesar disso, um modelo mais ou menos clássico, porque assentado no tempo da tradição, manteve-se praticamente inalterado. Como lembrou minha colega Giovanna Paduani, da Universitá di Roma, ao narrar o diálogo da menina Ana, de seis anos de idade, com seu pai: "- Papai, posso ligar o microfone para falar com a professora?". "- Pode, filha.", responde o pai. Ana liga o microfone e pergunta à sua professora, que estava online: "- Professora, posso ir ao banheiro?".

12 No campo do currículo, importante contribuição para o entendimento sobre o que é uma aula pode ser encontrada na definição de Sacristán (2008), para quem a aula pode ser compreendida a partir das relações entre um currículo oficial (prescrito e normativo), um currículo em ação (na prática) e um currículo oculto (centrado em elementos do subtexto da prática da aula). Alguns/algumas pesquisadores/as têm chamado a atenção para um outro tipo de currículo, compreendido como currículo nulo (ou vazio): aquele tipo de currículo que as escolas e seus/suas profissionais simplesmente eliminam de seus planos e atividades. Ou seja, um currículo de ausências. Cf. Moreira (1997). 
com os cotidianos ${ }^{13}$, têm buscado conhecer em profundidade o interior dessa "caixa preta"14. Esses investimentos têm contribuído para revelar uma realidade econômica, cultural, histórica, pedagógica e social bastante dinâmica, cuja análise se torna fundamental para a compreensão dos processos de escolarização e para a definição de políticas públicas para a área educacional.

A compreensão histórica sobre o que é uma aula ${ }^{15}$, que não deve ser apreendida como uma linha evolutiva, processual, contínua e uniforme e nem mesmo consensual, foi sinalizada por Cambi (1999). A título de representação, nada fidedigna das correlações de forças sobre rupturas e permanências históricas, Cambi (1999) destaca que na Grécia Antiga a aula ocorria no teatro e na ágora, tanto nos espaços públicos como nos domínios privados. Ela visava desenvolver o cidadão fiel à Polis e formar o sujeito em harmonia e no pleno desenvolvimento de si, uma "formação do homem através do contato orgânico com a cultura" (CAMBI, 1999, p. 49). Já no contexto medieval, as aulas eram quase um monopólio da Igreja Católica. Encrustadas no campo dos pensamentos religiosos, as aulas eram estabelecidas por conteúdos morais que deveriam ser estudados e cujos ensinamentos deveriam ser perseguidos durante toda a vida adulta em um tipo de formação dada em escolas monásticas e nas catedrais, tidas como palacianas e destinadas à formação de uma elite cristã pensante. Decorre dessa proposta pedagógica a expressão de um "desprezo pelo mundo" profano, como indica Cambi (1999, p. 163):

[...] o "desprezo do mundo" [pode ser entendido como] a humildade, a solidão e o silêncio, o amor a Deus e a consciência do pecado. [...] Um modelo de formação que

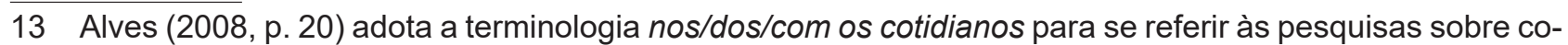
tidianos escolares tentando desmistificar o olhar "distante e neutro" das investigações acadêmicas tradicionais. Como procedimento teórico-metodológico as pesquisas sobre o cotidiano escolar representariam a imersão em um tipo de investimento não neutro capaz de contribuir para a composição de reflexões no campo da Educação.

14 Sobre a tentativa de abertura dessa "caixa-preta", Cf. os estudos sobre interação social na sala de aula desenvolvidos por Carvalho (1999); Delamont (1987); Resende (2004) e Sirota (1994).

15 Duas ressalvas são necessárias: a primeira a de que os/as historiadores/as da educação têm se debruçado mais sobre a compreensão da história da pedagogia a partir de diversos recursos historiográficos, de projetos de educacionais e de seus programas, de materiais e recursos didáticos, entre outras coisas e, talvez menos, sobre o tema específico da "aula" (VINCENT; LAHIRE; THIN, 2001). A aula continua a ser uma pequena peça nas engrenagens internas do processo social e histórico de escolarização. Além disso é preciso uma segunda ressalva: se se deseja fugir das armadilhas do anacronismo histórico, uma "história da aula", ainda por ser feita, deveria levar em consideração, assim como fazem os/as pesquisadores/as da história da pedagogia ou do pensamento pedagógico, o reduzido número de pessoas com garantia de acesso e de permanência na instituição de ensino escolar formal e regular. Talvez seja possível afirmar que um número realmente numericamente representativo de matrículas em escolas formais e regulares só conhece sua expressão, no Brasil, na democratização da escola pública a partir do século XIX. Salvo os casos pontuais, a história da escola, até antes do século XIX, no Brasil, é a história de uma elite escolar (de uma elite econômica). 
desenvolve os aspectos de interioridade e de sublimação, que invoca uma atitude de fuga da realidade para convergir para o crescimento de uma consciência que se mede na abertura para a transcendência, para a presença ao mesmo tempo forte e inefável do divino e, portanto, marcada por um conflito constantemente reaberto (entre Deus e mundo, entre pecado e salvação etc) na interioridade do sujeito.

Com o advento do período moderno, as famílias e as escolas passaram a se ocupar com maior zelo da experiência formativa dos indivíduos e com a própria reprodução cultural e social (NOGUEIRA, 2006). Não parece mera coincidência o fato de que as famílias e as escolas "se tornam cada vez mais centrais na experiência formativa dos indivíduos e na própria reprodução (cultural, ideológica e profissional) da sociedade” (CAMBI, 1999, p. 203). Datam desse período a invenção social da infância (ARIĖS, 2016) e a definição mais clara e precisa dos sistemas de ensino objetivando a construção de uma unidade de identidade nacional: a língua, as fronteiras, a história, os sistemas de pesos e medidas. Tudo isso a partir da escola, como registrou Ariès (2016, p. 159):

A partir do século $\mathrm{XV}$, as realidades e os sentimentos da família se transformariam: uma revolução profunda e lenta, mal percebida tanto pelos contemporâneos como pelos historiadores, e difícil de reconhecer. $\mathrm{E}$, no entanto, o fato essencial é bastante evidente: a extensão da frequência escolar. [...] Dessa época em diante [...] a educação passou a ser fornecida cada vez mais pela escola.

Os investimentos dos/as historiadores/as da educação produziram profícuos trabalhos sobre a escola moderna e o seu sentido, ainda que talvez poucos/as tenham se detido sobre o entendimento da aula como um problema teórico. No entanto um diagnóstico relativamente comum nos diferentes trabalhos foi a construção da laicidade do ato de ensinar, que passou a ser um aspecto relevante para as escolas e a modernização do ensino, com a presença do ensino privado e os ideais burgueses e mercantes. A produção do discurso escolar laico passou a destacar a educação como um direito social de e para todos/as, embora, talvez, essa promessa ainda não tenha se cumprido efetivamente nos dias hoje. Resta destacar que praticamente todos/as os/as principais intelectuais que escreveram sobre a escola, sobre o processo de escolarização ou sobre a sala de aula, são oriundos/as de um sistema escolar basicamente hierárquico, quase sempre orientado pela elite e que, apesar de diferentes clivagens de análises, é provável que também tenham internalizado em seus estudos algumas das sensibilidades burguesas, favorecendo o discurso de referência sobre as formas mais fundamentadas sobre a educação moderna. Como na máxima de que é preciso que tudo mude para que tudo fique igual, a escola continua reprodutora (BOURDIEU; PASSERON, 2008), mas atualmente a partir de novas práticas. Todavia, apesar das diferenças entre as formas clássicas e as formas novas de se compreender a escola, a sala de aula e 
a aula em si, é necessário sublinhar uma definição que parece mais ou menos comum sobre o que se pode entender como uma aula.

Como um conceito a aula é uma atividade do trabalho docente, expressão que serve para definir o fazer-trabalho cotidiano do/a professor/a. Ela difere das situações do trabaIho docente, todas as manifestações mais amplas do fazer-trabalho professoral que não estão prescritas oficialmente no fazer estrito do cotidiano dos/as docentes; tais como as conversas informais na hora do recreio ou os momentos de confraternização entre seus pares (SOUZA-E-SILVA; FAÏTA 2002). É justamente por isso que a aula, como categoria de atividade do trabalho docente, deveria ser primeiro explicitada por aquilo que não-é: a aula não é (ou ao menos jamais deveria ser) um "acerto de contas" entre professores/as, alunos/as ou estudantes, apenas uma "transmissão rasa" de conteúdos, um movimento de "congraçamento entre iguais", ou ainda um momento "panfletário".

Essa primeira tentativa de não-definição é sobretudo importante no Brasil atual, momento em que a aula está em evidência: a conjuntura que vivemos faz da aula (e de qualquer aula) uma possível "ameaça", campo minado para conflitos ideológicos e políticos, e quando não, partidários. Em tempos obscuros de conservadorismos, de intolerância à alteridade, de discursos revisionistas, negacionistas e mesmo anti-intelectuais, deriva de parcela da sociedade a preocupação com o controle do fazer e do tempo dos/as professores/ as. Apesar disso, a Constituição Federal assegura, em seu Art. 2065, a autonomia de cátedra. Tal autonomia garante o direito ao/à docente da liberdade de ensinar, assim como aos/ às discentes, a liberdade de aprender. Esse direito, conquista social inalienável, é a premissa básica para uma definição de aula em um Estado Democrático de Direito. Ou seja, os temas abordados em uma aula e a forma como são conduzidos, não poderiam passar por nenhum tipo de censura ao pensamento, como passaram muitas vezes as aulas nos períodos autoritários e ditatoriais. O fazer-trabalho do/a professor/a, suas atividades e situações de trabalho, só teria pleno sentido de existir em um Estado Democrático de Direito.

Infelizmente, em oposição ao direito do pleno e responsável exercício da atividade do trabalho docente, da liberdade pedagógica e do livre exercício do pensamento, um movimento conhecido por "Escola sem Partido", em nome de uma suposta busca por neutralidade política e ideológica, tenta se consolidar como um mecanismo de perseguição ao pensamento oposto, àquilo que poderia representar o direito ao contraditório, à diferença e à diversidade, bem como a autonomia dos/as professores/as no exercício de sua prática profissional. No entanto, qualquer aula é um exercício de não-neutralidade. Na educação, como em qualquer outro aspecto da vida, não há neutralidade possível uma vez que todo e qualquer ato de conhecer, de experimentar e de sentir, de ensinar e de aprender, é sem- 
pre um ato social que, ainda que se se pudesse "apartidário", restaria jamais efetivamente neutro.

\section{CONSTRUÇÃO CONCEITUAL COLETIVA SOBRE O QUE É TEORICAMENTE UMA AULA}

Embora o uso das ferramentas tecnológicas não seja ação totalmente novo no exercício da docência, tampouco da pesquisa, atualmente algo realmente inédito tem se desenhado: a crescente disponibilidade de conteúdos específicos destinados aos/às professores/as e aos/às pesquisadores/as, aos/às alunos/as e aos/às estudantes. À distância de um clique do mouse ou dos controles remotos e, literalmente, nas tecnologias touch screen da ponta dos dedos, o conhecimento didático-pedagógico está disponível para o acesso e a consulta de especialistas ou de leigos/as. Para se ter uma ideia do fenômeno a turma e eu encontramos, em consulta no Google, mais de 246.000.000 páginas dedicadas ao termo "Aula" no idioma português; a ocorrência de 529000000 registros para o francês "Classe"; 464.000 .000 para o italiano "Classe" e; 312,000,000 para o espanhol "Clase", para destacar apenas as três línguas neolatinas com maior número de falantes ao redor do mundo.

Para o termo em inglês, "Class", os números foram ainda mais expressivos: encontramos cerca de 4.280.000.000 ocorrências. A simples soma dessas cifras ultrapassa facilmente o número de dois bilhões de páginas. Se por um lado o resultado não garante que todas as páginas referem-se a "aula" como um saber didático-pedagógico produzido pelo conhecimento acadêmico de credibilidade e de qualidade científica, por outro podemos destacar, de maneira hipotética, que ainda assim parte considerável desse saber encontra-se disponível na forma de artigos, de comunicações de pesquisas, além de estar acessível em arquivos, bibliotecas, livrarias e museus virtuais. Na rápida consulta encontramos muitas imagens, da personagem de Mafalda, do argentino Quino (2002) e ainda planos de aula, publicações de conselhos sobre "Como dar uma boa aula?" etc. Em todos os casos, nenhuma ocorrência foi encontrada para responder especificamente à questão: "O que teoricamente é uma aula?".

Uma consulta ao dicionário Houaiss da Língua Portuguesa (HOUAISS; VILLAR, 2001, p. 344), por sua vez, apresentou um resultado mais satisfatório. O verbete "Aula" foi assinalado como:

[...] preleção sobre determinada área de conhecimento, feita por professore dirigida a um ou mais alunos, geralmente em estabelecimento de ensino, por período de tempo específico; lição. [...] Parte de um programa de ensino, no conjunto de um curso, transmitida aos alunos por professor por meio de textos; [...] explanação, elucidação ou exposição feita [...] por alguém que conhece bem o tema que aborda 
[...] trabalho ou desempenho que, por sua alta qualidade, constitui um ensinamento, uma lição.

Partimos da proposta do Dicionário como uma pista e nos apoiamos nos textos utilizados durante o semestre, que compõem as referências deste artigo, para a construção do conceito de aula como uma atividade político-pedagógica do trabalho docente. Composta por um dégradé de possibilidades analíticas caracterizamos a aula como o conjunto de postulados estruturantes inter-relacionados, cujo conceito mais preciso foi o que os/as estudantes e eu fomos capazes de elaborar. Eis o conceito de aula: a aula é uma atividade profissional que ocorre em tempos e em espaços específicos. Influenciada por condicionantes externos, ela pode ser compreendida como um dispositivo cultural destinado a/às alunos/as e estudantes com o objetivo de que construam suas próprias formas de (se) ver, de estar e de agir no mundo.

A elaboração do conceito, dada a partir de nossos investimentos em pesquisa e inúmeros seminários, originou a definição (ainda que bastante arbitrária) de quatro postulados: $1^{\circ}$. A aula é uma atividade profissional destinada a um momento formativo. $2^{\circ}$. A aula ocorre em tempos e em espaços específicos. $3^{\circ}$. A aula é regida por condicionantes externos e é um dispositivo cultural. E, $4^{\circ}$. A aula serve para que os sujeitos construam formas de ver e de estar no mundo. Esses quatros postulados, tomados como um conjunto de "sumário de pensamento", podem ser orientados pelos termos seguintes.

3.1 Primeiro Postulado: a aula é uma atividade profissional destinada a um momento formativo

Tal como a concebemos na atualidade, a aula é uma atividade profissional de uma categoria específica: os/as docentes. Essa categoria, no entanto, pode ter sua percepção alterada entre termos como professores/as, animadores/as, ensinantes, educadores/as, facilitadores/as, formadores/as, tutores/as etc., compreensões mais restritas, minimalistas, ampliadas ou alargadas da docência ou do sujeito que ensina. Não foi objetivo discorrer teoricamente sobre a diferença política na adoção desses termos. Interessa mais o registro de que a aula estaria para a categoria de docentes assim como um evento de fé estaria para um/a sacerdote/sacerdotisa, ou uma consulta clínica estaria para os/as profissionais de saúde. A aula é uma atividade demarcada por um exercício profissional, não importando sua tipologia: dialógica, expositiva, prática, presencial ou à distância, mais "tradicional" ou "inovadora", "alternativa" ou "progressista".

Isso significa que em termos teóricos a aula pressupõe um exercício de posição de autoridade: uma aula jamais é um encontro entre iguais. Ela exige uma vontade e um prota- 
gonismo docente, a existência de alguém capaz de a conduzir, seja em uma aula de dança, de direção que visa formar futuros/as condutores/as de veículos, de natação, de pilates, ou nos demais níveis e modalidades de ensino regular formal: em todos os casos há sempre uma pessoa (ou mais de uma) que sabe e que ensina e outra(s) que busca(m) aprender algo que desconhece $(\mathrm{m})$. À essa posição de autoridade compete todo um trabalho que a antecede e essa é a posição do/a docente envolvido/a em questões como planejamento, seleção dos conteúdos, definição dos materiais a serem utilizados e ainda os métodos e a organização a sistematização do tempo, as tipologias de avaliação da aprendizagem, etc. Assim, os/as futuros/as professores/as em formação saberiam mais sobre o que é uma aula se refletissem sobre para que e para quem ela serve.

Não à toa, no Brasil, os cursos de formação de professores/as são conhecidos como "cursos de licenciatura". De fato, trata-se de uma licença conferida pelo Estado às pessoas responsáveis por formar e preparar os sujeitos para a vida social. Como presunção, essa licença representa um capital cultural institucionalizado ${ }^{16}$, aquilo que confere ao/à portador/a da licença a responsabilidade de atuar como intérprete crítico/a da cultura e de seu tempo, herdeiro/a cultural eleito pela sociedade para a transmissão do conhecimento, mediador/a de culturas, de saberes e de práticas (MELLOUKI; GAUTHIER, 2004). Como afirmou Émile Durkheim (2011) o/a professor/a atuaria como sujeito comunicante e tradutor/a da cultura. Em termos mais simples: o/a licenciado/a é aquela pessoa a quem o Estado confere a autoridade para formar as futuras gerações. Isso significa que se um ato profissional é praticado sob a égide de um/a professor/a ele deveria ser realizado sob a proteção e com total amparo do Estado: os/as professores/as não são inimigos/as doutrinadores/as na sociedade. São eles/elas que dão as ferramentas necessárias para a construção e o ressignificado do sentido da vida em sociedade.

16 Segundo Bourdieu (2007) o capital cultural seria constituído por um conjunto de bens materiais e simbólicos capaz de produzir rendimentos sociais. Esse conjunto, na forma de três estados que se completariam, poderia ser resumido como a forma de um capital cultural incorporado, voltado aos conhecimentos adquiridos que se apresentariam como disposições duradouras dos indivíduos, aquilo que se referiria às competências em determinado campo do conhecimento, ao domínio da língua, da retórica e do conhecimento do mundo social e de seus códigos, por exemplo. Em sua forma de capital cultural objetivado, na realização e na segurança patrimonial de bens culturais socialmente valorizados, tais como a aquisição de dicionários, instrumentos musicais, livros, máquinas, obras de artes etc. E por fim, na forma de um capital cultural institucionalizado, fruto do reconhecimento dos outros dois tipos de capital cultural e que seria materializado nas aprovações em concursos públicos, nas certificações, nos diplomas, nos títulos ou nos resultados de proficiência e nas demais honrarias e premiações que de maneira geral serviriam para comprovar o reconhecimento das competências do indivíduo. Ao contrário do que ocorre na transmissão direta de herança dos bens econômicos e materiais, os três estados do capital cultural não seriam adquiridos sem a aprendizagem, o desejo e os esforços metódicos pessoais (esforços também socialmente aprendidos) que demandariam dos indivíduos o interesse, a valorização, o tempo e os investimentos necessários (condições objetivas, financeiras e materiais) para as aprendizagens. 
A aula é então a forma mais contumaz de uma "comunicação pedagógica" formal, uma ação coordenada principalmente pelo/a professor/a (por vezes podendo ser malsucedida, é claro) visando a transmissão de um conjunto específico de conhecimentos legados como relevantes para a formação do ser social. Tal comunicação pedagógica pode ser ilustrada como uma situação de interação social

[...] de aula em uma classe - por exemplo, de 50 alunos, organizados em fileiras de cadeiras em direção a um tablado e um quadro-negro, onde o professor ensina (portando as qualificações oficialmente necessárias para tanto) os conteúdos disciplinares (chancelados pela autoridade pública competente) para um determinado nível de ensino em uma instituição educacional formalmente reconhecida. (BONALDI, 2015, p. 288).

Isso revela que a relação entre docente e educandos/as é sempre uma relação de poder e de autoridade. Compreender a aula como uma categoria analítica exige entender a relação de desigualdade existente entre professor/a e alunos/as ou estudantes. Nessa relação desigual, a aula pode ser representada, por alunos/as ou estudantes, como um "tempo perdido", como uma atividade desconexa de seus desejos (por diversas vezes não sem razão) como restou evidente a fala de uma aluna secundarista que em 2016 fez frente ao governo de Michel Temer:

[...] o movimento estudantil nos trouxe um conhecimento muito maior sobre política e cidadania do que todo o tempo que nós estivemos sentados enfileirados em aulas padrões. Uma semana de ocupação, que nós estamos, nos trouxe mais conhecimento sobre política e cidadania do que muitos outros anos que a gente vai ter dentro de sala de aula. (Ana Júlia, 2016. Transcrição minha) ${ }^{17}$.

A compreensível insatisfação discente não deveria produzir um discurso anti-intelectual sobre a aula baseado em noções atualmente pouco profundas como "relações horizontais", "auto-gestão" e uma "educação que não seja baseada na autoridade" em oposição a "aulas padrões" sob o risco de que a juventude da classe trabalhadora pudesse ser representada como raramente aspirando a educação como força motriz para a participação política e a construção da cidadania.

17 No segundo semestre de 2016 alunos/as e estudantes de todo o Brasil matriculados/as em instituições públicas e privadas de ensino se manifestaram contra as ações políticas adotadas pós-impeachment da primeira mulher eleita democraticamente Presidenta da República para o exercício do cargo de seu segundo mandato em 2014. Algumas frentes populares resistiam contra a Emenda Constitucional n. 95/2016 que, aprovada em dezembro daquele ano, congelou os gastos públicos federais em educação por 20 anos. Pelo "Novo Regime Fiscal" os gastos públicos passam a ser corrigidos apenas pela inflação do ano anterior com base na variação do Índice de Preços ao Consumidor Amplo (IPCA). Naquela época as notícias de mobilização pelo País contabilizavam mais de 1.100 Escolas ocupadas e mais de 50 Universidades e de 80 Institutos Federais em todo o território brasileiro. Não houve nenhuma cobertura relevante da grande imprensa nacional. Cf. o vídeo "Ana Júlia, secundarista de Curitiba na Assembleia Legislativa - Ocupação" de 26 de out. 2016 publicado pelo canal do YouTube Canal 2 e disponível em: <https://www.youtube.com/watch?v=fPGJjO-zdn4>. Último acesso em 21 jan. 2018. 
Talvez parte considerável dos/as jovens de hoje compreenda a escolaridade obrigatória como uma chata e irrelevante rotina necessária para a garantia de seus prováveis maçantes e enfadonhos empregos futuros, quase a forma de um cárcere intelectual necessário. Infelizmente grande parte dos processos de escolarização não oferece hoje condições estáveis e coesas capazes de produzir rotas diferentes de "aulas padrões". Ao menos aparentemente o capital cultural, especificamente aquele forjado na e pela escola, estaria cada vez menos autônomo e mais associado aos capitais econômico e social. Entretanto o capital cultural institucional, representado pela chancela de um título, ainda permanece importante, ele se mantém como uma referência quase hegemônica no mundo do trabalho. Isso explicaria o forte apelo das famílias, sobretudo das frações das camadas populares, pela escola. De alguma maneira as famílias ainda percebem que somente a escola pode conferir aquilo que crianças, jovens e adultos/as precisam e/ou desejam: o diploma. Na contemporaneidade se a certificação não é mais suficiente ela é cada vez mais necessária, inclusive para o pleno exercício da cidadania. A negativa dessa premissa pode ser muito perversa, sobretudo para as camadas populares que ainda projetam na escola as suas expectativas de futuro.

3.2 Segundo Postulado: como um evento, a aula ocorre em tempos e em espaços específicos

Para fins teóricos, a aula pode ser compreendida como um evento que ocorre na relação entre o mundo social e as experiências particulares dos indivíduos socialmente produzidos. O Dicionário Houaiss da Língua Portuguesa (HOUAISS; VILLAR, 2001, p. 1.277) define como evento um "[...] acontecimento geralmente observável, fenômeno [...], fato, ação, processo", como algo que acontece.

A adoção do termo evento permite localizar as pessoas como sujeitos independentes e intencionais em suas ações, ao mesmo tempo em que são identificados os padrões que orientam suas escolhas e motivações; como elas significam e justificam suas opções e percursos escolares, favorecendo a análise de como essas mesmas pessoas são produzidas socialmente. Ao compreender a aula como um evento social cada sujeito, em decorrência de suas experiências no mundo, de suas disposições ${ }^{18}$ incorpora de modo singular esquemas de ação, de apreciação, de interpretação, de percepção e de valorização, que são socialmente construídos. Esses esquemas de ação podem mudar ao longo do tempo, em relação às experiências das pessoas, se conformando ou resistindo às condições objetivas às quais os indivíduos se expõem.

18 Considero por disposições as expressões dos processos sociais, simbólicos, discursivos e/ou materiais por meio dos quais os sujeitos se tornam indivíduos de determinado tipo (LAHIRE, 2004) aprendendo socialmente as formas de ser, de estar e de agir no mundo. 
Na condição de um evento, a aula pode ser tanto um processo descontínuo e não linear de experiências pessoais e profissionais como o resultado de um desencadeamento mais ou menos intencional, lógico ou reflexivo dos efeitos socializadores conformados pelas aspirações, as mobilizações, os investimentos e as estratégias familiares, resultado determinado pelas condições econômicas e pelos estados do capital cultural. Mas se aula pode ser entendida como um evento, ela também pode ser analisada como um encontro, um acontecimento formativo que ocorre em tempos e em espaços específicos. Ela pode ocorrer em uma sala, um laboratório ou uma quadra poliesportiva (dentro de um estabelecimento de ensino regular e formal), ou em espaços informais (como praças e demais espaços públicos), em espaços formativos não-escolares (museus, observatórios ou laboratórios) e ainda em espaços virtuais de aprendizagem (à distância e/ou pela internet). Os espaços formais têm como referência o fato de que as aulas ocorrem em espaços sociais historicamente inventados para a sua finalidade; ou seja, os estabelecimentos de ensino, as creches, as escolas e as universidades são conquistas sociais históricas inventadas (não sem muitos conflitos de interesses) para formar para a vida em sociedade. Esses espaços, físicos, materiais e objetivos, permanecem consolidados na cultura educativa ao longo da história escolar.

Os espaços formativos não-escolares, por sua vez, são plurais e guardam uma simetria que Ihes parece intrínseca: a noção de que nada se compara ao corpo que aprende. Por mais interessante que seja o livro didático, por mais interessante que sejam os sítios eletrônicos, poder tocar, ver, sentir, faz da aula uma potência de aprendizagens. E justamente por isso os estabelecimentos de ensino preparam excursões ou trabalhos de campo, atividades práticas e de experimentações destinadas aos/as/às alunos/as e estudantes. Isso faz com que as fronteiras do espaço de uma aula estejam sempre borradas: a aula pode ocorrer tanto dentro como fora do espaço físico escolar. O que a define não é, portanto, o espaço físico em que ela ocorre, mas como o espaço em que a aula ocorre pode se tornar uma forma de paisagem social (ZARANKIN, 2001) de aprendizagem, um dispositivo eficaz para o cumprimento de sua função educativa. O espaço adquire importância para a aula porque se vincula à forma como as pessoas interagem entre si e com conhecimento comunicado e/ ou produzido. Nesse sentido os espaços escolares e não-escolares são constituídos como sistemas de significado que podem ser lidos e aproveitados para se tornarem espaços de aula. É assim, por exemplo, que um/a professor/a em seu horário de folga pode encontrar ao acaso um/a estudante em um cinema, sem que o local seja um espaço de aula e, na semana seguinte, o/a professor/a decidir por levar a sua turma para uma sessão comentada de um filme, objeto de um conteúdo escolar, em que o mesmo cinema se transforme em um espaço de aula. 
Uma aula é sempre um evento condicionado pelo tempo que concorre com ela mesma: há um tempo de duração a ser cumprido - a execução de horários e as dinâmicas de intervalos e de descanso, rituais próprios da escola (MCLAREN, 1991). Atravessada pelo tempo, a aula possui um começo, um meio e um fim. E apesar disso uma aula também pressupõe uma relação de suspensão desse mesmo tempo cronológico. De maneira transgressora, ato político e de resistência, a aula rompe com o tempo na medida em que pode desligar as pessoas da realidade do aqui e do agora (MASSCHELEIN; SIMONS, 2014). Por diversas oportunidades os/as professores/ as experimentam o resultado dessa suspenção temporal quando a aula é interrompida, ora por necessidades objetivas para o prazo de encerramento de uma exposição, ora por uma sensação de imersão no conteúdo. De toda maneira parece bastante sugestivo e muito significativo para o/a docente quando uma aula precisa acabar e o/a professor/a escuta de seus/suas interlocutores/as expressões como: "Mas a aula já acabou?" ou "Eu nem vi a hora passar!".

Quando o tempo da aula é redimensionado é provável que a atividade de trabalho docente tenha significado um momento de escuta sensível e um espaço de acolhimento, uma oportunidade para que os sujeitos tenham efetivamente construído as condições para um encontro de propósito mútuo: o diálogo científico sobre algo. Obviamente nem sempre as condições para esse diálogo são estabelecidas e nesses casos o tempo cronológico da aula pode ser um triste ensaio de resistência para o término de atividades pedagógicas aborrecidas. Mas há ainda outros tempos da aula: aqueles que perduram, intencionalmente ou não. Do ponto de vista intencional o aspecto mais relevante de duração relativa do tempo-aula seriam as atividades de estudo e de pesquisa destinadas a um tempo extraescolar, tais como os para-casas ${ }^{19}$. Do ponto de vista não-intencional, aspectos de reflexão que, oportunizados pela aula, surgem após a explicação de um termo, de um conceito ou de um conteúdo, algo que apenas depois da aula alunos/as e/ou estudantes encontrarão pela vida. Para esse caso não é incomum que a experiência docente seja marcada por narrativas de alunos/as e estudantes que interpelam seus/ suas professores/as para manifestarem que um objeto da aula foi conhecido, tempos depois, em veículos de notícias. Quando isso ocorre, professores/as escutam comunicações como: "Ontem eu vi uma notícia no jornal sobre o que você falou em sala" ou "A TV falou sobre o que a gente estava estudando" ou ainda "Conversei com meus pais sobre o tema da aula...".

3.3 Terceiro Postulado: dispositivo cultural, a aula é regida por condicionantes externos

Condicionantes externos podem ser facilmente assimilados por professores/as e instituições escolares ou, por haver resistência, enfrentarem dificuldades para determinar a

19 Para saber mais a relação tempo-aula e as atividades extraescolares a partir da referência da Sociologia da Educação Cf. Resende et al. (2018). 
atividade do trabalho docente. A aula é sempre a menor parte de um planejamento maior, tal como uma peça de um mosaico, definida por condicionantes normativos, parte de um currículo prescrito. Entretanto, há também condicionantes relativamente pouco perceptíveis no cotidiano de professores/as e de alunos/as ou estudantes. Os exemplos seriam as definições dadas pelo Estado, a macro política pública formativa, os limites de intervenções conferidos pelas legislações educacionais, os dispêndios econômicos destinados aos investimentos educacionais (recursos didático-pedagógicos, a qualidade do ambiente educacional etc), os marcos teórico-pedagógicos, os procedimentos das metodologias de ensino, as tipologias e os critérios de enturmação das classes, os diversos tipos de currículo ou de sistemas de avaliação e assim por diante. Como um dispositivo cultural, as aulas compõem a menor parte dos programas de ensino e também a sua parcela mais específica. As aulas, na forma de um currículo em ação ou na ocorrência de um currículo oculto, podem ou não se relacionarem com o currículo oficial e igualmente com todo um conjunto social maior que as estabelece: a formação dos/as professores/as, as políticas educacionais e as definições formativas dadas pela sociedade. Assim, talvez seja possível afirmar que toda e qualquer aula é determinada por um conjunto de fatores multifacetados que se encontram associados a experiências diversas que são anteriores ao (ou mesmo maiores que o) exercício da atividade de trabalho docente, aquilo que poderia ser compreendido apenas como a parte invisivel, como na analogia com a ponta do iceberg.

Alguns aspectos dessa ponta do iceberg podem ser encontrados na Figura 01. Tal como uma rotulagem, a Figura 01 apresenta os códigos sociais de condicionantes externos que podem influenciar uma aula. Essa rotulagem parte do princípio de que a aula está localizada em uma arena social, expressão de uma possibilidade de explicação do espaço social no qual buscas de diferentes formas de saber e interesses são estruturados e pautados em distintas relações de poder, construindo, de maneira dinâmica, as relações sociais. De outra maneira, a arena social não seria um espaço simplesmente ocupado por quem (ou aquilo que) supostamente detém o poder de ensinar, mas "um espaço onde se viabilizaram (e inviabilizaram) ações políticas coletivas" (POPKEWITZ; PEREYRA, 1992, p. 25), tecidas com base em configurações específicas de conhecimento.

Dessa forma, contradições, conflitos, distorções, resistências, tensionamentos e disputas por espaços, narrativas ou representações que envolvem as aulas podem ser analisadas em termos de ações sociais coletivas que precedem as práticas dos/as docentes. Em primeiro lugar, porque são nas próprias ações sociais coletivas que se encontram as raízes desses fatores de (e em) disputa. Em segundo lugar, porque é na trama da arena social que a aula adquire e produz o seu sentido. E, em terceiro lugar, porque a aula guarda a possibilidade de compreender as tendências e as contra tendências, as acomodações e 
as resistências; o que faz da arena social uma parte significativa (e explicativa) da estrutura social.

Figura 1 - Arena Social e os condicionantes externos de uma aula.

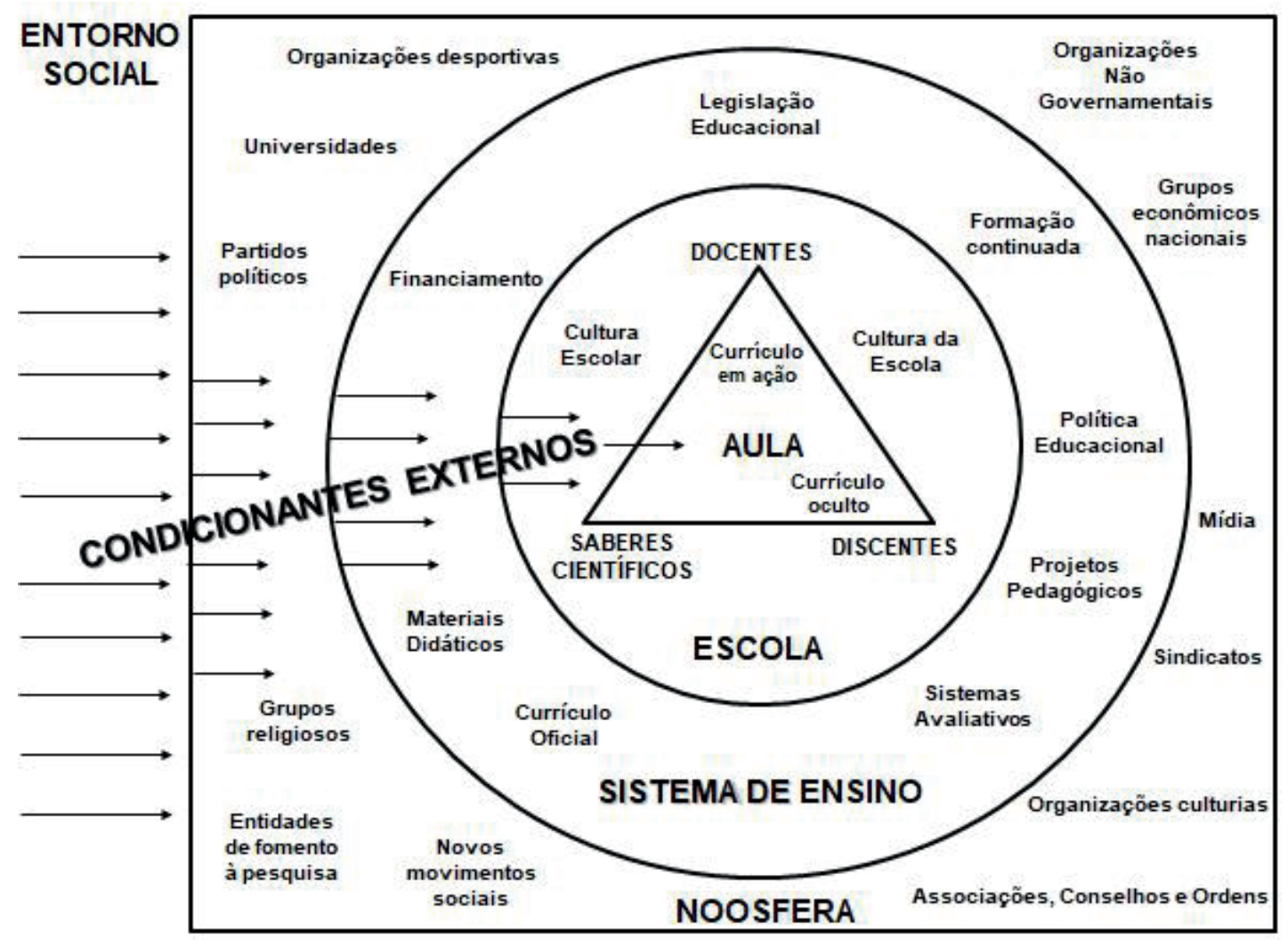

Fonte: Elaborada pelo autor.

A primeira parte mais externa a determinar uma aula é o seu Entorno Social: aspecto mais disperso da vida humana que envolve questões e temas que no dia a dia apenas acontecem. Ele simplesmente existe. Quando um/a professor/a do ensino de matemática escuta do/a aluno/as que não precisa aprender trigonometria para ir à farmácia, isso faz relativo sentido. Infelizmente, muito do que se aprende na escola não possui relação com (embora esteja amparado pelo conhecimento do) entorno social, o eixo mais comum do cotidiano das pessoas. Isso explica porque os/as alunos/as, embora mentalmente e de maneira não-reflexiva, operam cálculos complexos ao atravessarem a ruas em frente à escola após uma aula de Física sem necessariamente lembrar da fórmula cinemática para o cálculo da velocidade dos corpos. Ou porque estudam os conceitos físicos da termodinâmica e continuam a repetir, em estações mais frias, que dormem sob cobertores para "esquentar o corpo" quando na verdade apenas se cobrem para evitar a transferência de calor. 
Uma parte das questões e dos temas que nos atravessa no dia a dia ganha espaço na Noosfera: a esfera do pensamento social humano em sua forma mais organizada, mais elaborada que, constituída por um mundo de ideias, traduz e significa ações e produtos culturais compondo a maneira pela qual as pessoas pensam e agem e em torno do que se mobilizam.

Apenas parte de tudo do que a sociedade produz e que foi inventada e sentida pelo Entorno Social ganha espaço na Noosfera e, após novo filtro, uma outra parte, menor e não mais tão correlata às experiências do Entorno Social e da Noosfera, chega enfim ao Sistema de Ensino. Como uma arena de poder em que estão em disputas interesses e privilégios, tradições e invenções, também uma parte do conhecimento historicamente acumulado e validado pelo poder do Estado segue em direção à Escola. Uma vez no estabelecimento de ensino, as determinações legais podem ser incorporadas, transformadas ou apenas rejeitadas. É nesse ponto que parte do contrato pedagógico é estabelecido entre professores/as e alunos/as ou estudantes. É a relação didática que influenciará mais diretamente a Aula. Ou seja, a aula seria o resultado de um grande filtro social.

De maneira geral o estudo da história do processo educacional escolar, aquilo que inventou a aula como um evento formativo, indica que o terreno para a aquisição do conhecimento foi sendo estabelecido por meio de uma massificação da escola (forjando assim a cultura escolar), por um crescente número de disciplinas escolares que exigiram regulamentações e que inventaram procedimentos mais ou menos adequados de ensino. Obviamente os condicionantes exteriores de uma aula possuem efeito temporário, já que não se fixam perpetuamente. No entanto, como um fenômeno transitório e não definitivo, seus efeitos podem ser sentidos por diferentes gerações, ao longo de muito tempo, mantendo-se na história escolar de muitas pessoas e de muitos programas de ensino em diferentes escolas $^{20}$. Isso explicaria porque a minha mãe continua a usar a expressão matemática tirar a prova dos noves ou noves fora ao se referir a ter certeza sobre algo.

20 Williams (1961) lembra que a educação obedece à uma tradição seletiva em que os conteúdos escolares seriam o fruto de pelo menos três tipos de reações históricas: na primeira, conteúdos legados como patrimônios humanos de conhecimento e que estariam mais assentados na tradição escolar. Esses conteúdos, de alguma forma tidos como relevantes e indispensáveis para toda a humanidade, guardariam características mais clássicas e universalistas e justamente por isso seriam mais consolidados no tempo da longa duração (como o estudo da mecânica clássica e as leis de Newton, por exemplo). Na segunda reação histórica estariam os conhecimentos que sofreriam de maior ou de menor aderência aos interesses do conhecimento escolar. Esses conhecimentos seriam mais localizados e não interessariam, necessariamente, um conhecimento baseado em princípios universais e por isso gozariam de prestígio momentâneo estando, pois, à mercê de toda sorte de mudanças culturais, econômicas e políticas que se organizam no tempo da curta duração (conhecimentos, sobretudo históricos, que seriam passíveis de reconstrução e que ganhariam ou perderiam facilmente status no currículo escolar. Um exemplo claro seria a figura de Tiradentes, personagem histórica cuja construção de herói nacional só foi possível após a inauguração - e os interesses - da República. Outro exemplo, o da regra dos nove; aprendido por minha 
Cabe ressaltar que a Figura 01 não apresenta como os atores sociais estão dispersos nessa arena social, algumas vezes ocupando mais de uma posição e ao mesmo tempo. Por exemplo: um/a professor/a da educação básica pode ser estudante em um curso de pós-graduação, ocupar um espaço representativo em um partido político progressista e, em função de sua associação particular a um determinado grupo religioso, possuir uma dissonância cognitiva sobre temas presentes no entorno social como o aborto, a descriminalização do uso de maconha para fins recreativos e outros tantos temas tidos como "polêmicos". Não obstante, talvez seja comum que os/as alunos/as questionem essa pessoa sobre esses temas durante as aulas, simplesmente por se tratar de temas da vida dos/as próprios/ as alunos/as, temas de nosso tempo, ou porque eles esbarram em conteúdos escolares.

Outro exemplo ilustrativo sobre os limites da rotulagem apresentada refere-se à Lei Federal n. 11.645 sancionada pelo Presidente Lula em 2008. A lei que estabeleceu a inclusão, no currículo oficial da rede de ensino, da obrigatoriedade da temática "História e Cultura Afro-Brasileira e Indígena" nas diretrizes e bases da educação nacional (como qualquer lei) pode ou não ser adotada nas escolas. A questão racial está e sempre esteve presente no entorno social brasileiro. Já na noosfera, como resultado da pauta do ativismo de militantes interessados/a na narrativa e na representação da população negra (e na garantia de seus direitos), de maneira organizada, a questão racial passa a pressionar o Estado para chegar à escola. No caso específico do Brasil a temática ganhou espaço no sistema de ensino a partir da Lei. Obviamente as intenções da Lei podem ou não chegar à sala de aula. Não sejamos inocentes: a questão da ancestralidade negra africana pode ser objeto de conteúdo de uma aula e ser utilizada tanto para reforçar como para desconstruir estereótipos e preconceitos.

Sem desejar relativizar a questão é importante destacar que a legitimação ou a deslegitimação do que se deve ou como se deve ensinar, aspecto mais íntimo da construção de uma aula, não surge e tampouco desaparece porque tenha adeptos/as ou porque seja lei. Apenas a existência de uma lei, per se, não seria capaz de alterar as relações sociais que envolvem o racismo. Hipoteticamente um/a professor/a branco/a poderia simplesmente resistir à Lei e não assumir, com compromisso ético, a responsabilidade de formar as futuras gerações tendo em vista a construção de uma sociedade mais equânime, seja por "falta de formação", argumento bastante presente entre colegas professores/as, seja por simples desinteresse,

mãe na escola e atualmente um conhecimento inusual). Por fim, a terceira reação que indica que certos conhecimentos jamais chegaram de fato às escolas pois que se perderam no tempo e sobre o qual pouco ou nada temos de registro (tal como o conhecimento popular da Biblioteca de Alexandria, perdido pela mítica devastação de um incêndio ou o resultado da destruição de diversos livros durante o Nazismo, que faz-se necessário indicar, foi um movimento de extrema-direita). 
seja por acreditar que aquele conteúdo não seria importante. Da mesma forma é possível que o exercício profissional de professores/as negros/as não tenha sido alterado pela Lei: antes e depois dela o tema continua presente em suas aulas. Entretanto, é a existência da Lei que garante e que estabelece o reconhecimento das práticas de docentes interessados/as na construção de uma história mais igualitária e inclusiva, referendando e legitimando práticas que não poderiam e nem deveriam ser questionadas por terceiros. Assim, o sistema de ensino acaba por balizar e por legitimar a aula, autorizando os/as professores/as em seus papéis de intérpretes da cultura e de seu tempo. É na disputa pela Escola, parte dessa arena social, que movimentos como o "Escola sem Partido" atua. E isso por representar um enorme risco às atividades do trabalho docente e ao Estado Democrático de Direito no Brasil.

3.4 Quarto Postulado: a aula serve para que os sujeitos construam formas de ver, de estar e de agir no mundo para manter ou mudar esse mundo

A aula opera um conjunto complexo de informações, de ficções, de ideologias, de teorias, de exemplificações, em que hipóteses são testadas e onde o saber do senso comum produz debates com os saberes tradicional, científico, técnico ou teórico. O conhecimento historicamente acumulado, selecionado, organizado e possível de ser transmitido (WILLIAMS, 1961) encontra na forma de uma aula a única maneira possível para que alunos/as ou estudantes possam aprender e empreender algo realmente novo no mundo (ARENDT, 2002). Em outros termos: a aula cumpre uma função social; a de produzir momentos formativos que visem a autenticidade, a criatividade e a positivação das práticas de aprendizagens dos indivíduos na sociedade.

Uma aula, qualquer que seja a sua forma, é sempre a tentativa de uma comunicação. Uma aula é uma função fática: ela se assenta na interlocução entre sujeitos; é lugar de fala e de escuta, lugar de escrita, lugar para testes do conhecimento e espaço para produção de saberes e de ensaios. Movimentos gestuais, cálculos e fórmulas, cartografias, experimentos, imagens e sons, jogos e mapas são também maneiras ampliadas de um texto que é ensinado para a leitura do mundo.

Paulo Freire (2011, p. 19-20) ressaltou que "a leitura do mundo precede a leitura da palavra". Sendo assim, linguagem e realidade, escola e entorno social, se prenderiam dinamicamente. Isso significa que a "leitura do mundo" só pode ser compreendida em sua totalidade se a relação didática que se estabelece em uma aula for entendida de forma crítica e política. Trata-se não apenas da alfabetização pela palavra, mas mais de um conjunto de alfabetização para ler, (de-)codificar, pensar o mundo e nele atuar. Assim, a decodificação das letras, das palavras e das expressões deveria originar uma consciência histórica e um 
letramento em que os sujeitos reconhecessem o/a outro/a e a si mesmos como sujeitos de história e ao mesmo tempo como sujeitos na história, sujeitos de direitos mas também de deveres para com o compromisso com a/na vida pública.

Importante para a construção de sua identidade e de sua autonomia como sujeito social, a aula deveria dar voz às narrativas e experiências dos/as educandos/as. Com isso, a educação reafirmaria o respeito aos/às alunos e estudantes, buscando compreender aquilo que os toca, que os marca afetivamente e a maneira como constroem seus significados e o sentimento de pertencimento no dia a dia. Ler o mundo é ter condições de fazer escolhas mais conscientes e ao mesmo tempo respeitar ao senso de tradição que envolve uma aula. Ler o mundo é muito mais do que decorar datas e acontecimentos, nome dos rios e de seus afluentes, mais do que decorar fórmulas ou tabelas. Ou melhor, ler o mundo é superar isso, é conhecer-se sujeito capaz de agir nos limites e nas possibilidades de seu tempo e de seu espaço de maneira ética.

Uma aula exige abstração, senso crítico, faculdade intelectiva e cognoscitiva humana. É na aula que alunos/as e estudantes encontram a oportunidade de aprender, de descobrir e de testar algo, coisas, aquilo que não fariam se não estivessem nesse lugar. Ou, nos termos de Forquin (1993, p. 173):

\begin{abstract}
Educar, ensinar, é colocar alguém na presença de certos tipos de elementos da cultura a fim de que ele deles se nutra, que ele os incorpore à sua substância, que ele construa a sua identidade intelectual e pessoal em função deles. Ora, um tal projeto repousa necessariamente, num momento ou noutro, sobre uma concepção seletiva e normativa da cultura.[...] [A escola, ou A aula] é um lugar específico, onde os membros das gerações jovens são reunidos por grupos de idade a fim de adquirir sistematicamente, segundo procedimentos e modalidades fortemente codificadas, disposições e competências que não são do mesmo tipo das que eles teriam podido adquirir ao acaso das circunstâncias da vida e em função de suas demandas espontâneas. Aqui se obtêm respostas a questões que não seriam jamais colocadas em outros lugares. [...] Estamos determinados a transmitir alguma coisa que valha para os que nos seguem [...] Sujeitos à finitude, e sabendo disso, nós não temos, ao final das contas, outra escolha senão querer para os outros a vida e confiar-Ihes nosso testamento.
\end{abstract}

Dessa maneira uma aula, teoricamente, poderia servir como guia de pensamento para que alunos/as e estudantes compreendessem o mundo em que estão (e quão desigual ele ainda é), quem eles/elas são e quem desejam se tornar agindo neste mundo.

\title{
4 PENSAMENTOS À GUISA DE CONCLUSÕES: UMA AULA SERVE PARA NÃO SERVIR
}

Neste texto foram produzidas algumas definições teóricas, a partir da contribuição do campo da Sociologia da Formação e da Profissão Docente e de um tipo de método de 
pesquisa-ação, para o conceito de aula. Locus fundamental da existência da prática docente, a comunicação pedagógica de uma aula sinaliza a produção e a reprodução da vida, da cultura e da política de uma sociedade em um determinado contexto histórico.

A aula está presente nos tempos de curta, média e longa duração da história social da pedagogia e da escola, nos mais variados espaços e lugares, em diferentes circunstâncias e sociedades, em toda a sua complexidade, imprevisibilidade e contraditoriedade; em sua renovada incompletude de (des-)encontros. A aula desafia, interroga, implica, não apenas a capacidade analítica e reflexiva da teoria pedagógica, mas, no cotidiano, os/as professores/as e seus/suas alunos/as e estudantes. Na condição de atividade do trabalho docente, criada e recriada pelo Estado, pela pedagogia e pela didática, pelo currículo e pelos interesses dos sujeitos ou dos fluxos dos movimentos coletivos, nos múltiplos cenários, cenas e enredos da escola e da práxis social, a "caixa-preta" da aula ainda pode ser objeto de investigação sobre o ofício dos/as professores/as e sobre a escola.

O resultado dessa "caixa-preta" é sempre incerto, por mais que existam condicionantes externos conhecíveis e passíveis de serem controlados simplesmente porque uma aula nunca é igual a outra: ela faz parte de universos culturais plurais, está em disputa, no centro de uma arena social de luta por narrativa, poder e representação, em uma tênue relação de movimento que ao mesmo tempo afasta e aproxima desiguais: docentes e discentes. A aula é, antes de tudo, um trabalho intelectual. É possível que a compreensão desse fenômeno possa oferecer aos/às estudantes das licenciaturas um frescor para problematizações acadêmicas futuras: para entender as desigualdades persistentes na sociedade e na escolaridade, há muito tempo temas centrais nas pesquisas educacionais, talvez seja preciso um exercício de imaginação sociológica sobre a aula de maneira que novos/as pesquisadores/ as tenham a paciência científica para continuar a invocar, a reinterpretar, a medir e a testar conceito(s) de aula.

Tal como este artigo teve início eu não poderia deixar de terminá-lo sem evocar uma outra narrativa episódica. Em 2018 comentei em uma turma de mestrandos/as com a qual eu trabalhava que estava produzindo um artigo sobre essa temática. No último dia de aula, uma estudante de 35 anos e já professora rede pública estadual de Minas Gerais, ao avaliar qualitativamente a disciplina, disse público: “- Pela primeira vez eu estou pensando sobre o meu lugar neste mundo, estou me descobrindo, desconstruindo preconceitos, como mulher e como professora". Depois da última aula do semestre letivo a professora mestranda me enviou um e-mail, que após a sua autorização parcialmente reproduzo:

[...] Quando iniciei o mestrado na sua disciplina a minha primeira fala foi a de que eu não tinha ou não reconhecia um lugar de fala. Hoje, digo que reconheço esse 
lugar. Lugar ainda de palavras incipientes, vacilantes, que expressam concepções inicialmente frágeis. Reconheço-me, hoje, como mulher negra, periférica, neta de avó benzedeira, curandeira e erveira e de avô negro que tirava o sustendo da família do trabalho físico. Hoje, também, sei que o ensinaram que esse seria o único lugar possível para ele ocupar. [...]

Gostaria que soubesse, professor, que a aula me trouxe de volta. De volta para mim mesma, para minha sensibilidade e habilidades intelectuais. Reconheço-me livre dos grilhões que me aprisionavam, dos estereótipos que me convenciam do meu não-valor. Nesse sentido, me pego escrevendo de forma consciente, mesmo que de forma superficial sob o ponto de vista sociológico. Sei o meu lugar de fala, o lugar que quero estar, a educação que quero defender por meio da minha voz. [...]

As histórias de escola são histórias de amor e eu não poderia deixar de dizer que a minha história com essa disciplina e com as aulas foi e continuará sendo uma história de amor. De amor fraterno, de amor pelo saber, do amor pelo que liberta e pelo que se alegra em ver o outro florescer.

Por uma educação para liberdade!

Talvez uma aula seja um bem imaterial da sociedade, um tipo de audiência pedagógica e um plebiscito diário para tantos/as professores/as, alunos/as e estudantes. Nos dias de hoje, embora outras funções educativas sejam exercidas por meio de grupos familiares e de amigos, de igrejas, de meios de comunicação e de informação, de redes sociais virtuais ou mesmo à distância; a aula, nos ambientes escolares regulares formais de educação, continua a ser produzida como um artefato cultural relevante e um espaço significativo para o processo de ensino-aprendizagem.

Uma aula, qualquer que seja seu tema ou conteúdo, deveria servir para que as pessoas se perguntassem como as coisas são e como gostariam que as coisas fossem. E os/ as professores/as poderiam saber mais sobre a sua responsabilidade de ensinar se reconhecessem e respeitassem a sua autoridade profissional, compreendendo a aula como uma atividade profissional destinada a um momento formativo que serve para que os sujeitos construam formas libertárias e libertadoras de (se) ver e de estar no mundo. Uma aula deve, sobretudo, servir para não servir.

Para Ana Céu e Caetano, filha e filho de uma pesquisadora e de um professor, que mesmo no isolamento provocado pela COVID-19 continuaram gostando de (e se divertindo com as) suas aulas. Também às suas professoras, que com suas aulas formam as minhas crianças para atuarem neste mundo. 


\section{REFERÊNCIAS}

ALVES, Nilda. Decifrando o pergaminho: os cotidianos das escolas nas lógicas das redes cotidianas. In: OLIVEIRA, Inês Barbosa de; ALVES, Nilda (Org.). Pesquisa nos/dos/com os cotidianos das escolas: sobre redes de saberes. Petrópolis: DP\&A, 2008, p. 15-38.

ARENDT, Hannah. A crise na educação. In: ARENDT, Hannah. Entre o passado e o futuro. Trad. Mauro W.B. de Almeida. 5. ed. 2. reimp. São Paulo: Perspectiva, 2002, p. 221-247.

ARIĖS, Philippe. História social da criança e da família. 2. ed., 1. reimp. Trad. Dora Flaksman. Rio de Janeiro: LTC, 2006.

BARROSO, João. Cultura, cultura escolar, cultura de escola. 1. ed. São Paulo: UNESP/ UNIVESP, 2012.

BONALDI, Eduardo Vilar. Articulando os níveis micro e macro na análise da comunicação pedagógica: a interação face a face e sua estrutura social. Educação em Revista, Belo Horizonte. v. 31. n. 02, p. 281-307, abr./jun. 2015.

BONDÍA, Jorge Larrosa. Notas sobre a experiência e o saber de experiência. Trad. de João Wanderley Geraldi. Revista Brasileira da Educação, Rio de Janeiro, n. 19, p. 20-28, jan./abr., 2002.

BOURDIEU, Pierre. Os três estados do capital cultural. Trad. Magali de Castro. In: NOGUEIRA, Maria Alice; CATANI, Afrânio (Orgs). Escritos de educação. 9. ed. Petrópolis: Vozes, 2007 p. 71-79.

BOURDIEU, Pierre; PASSERON, Jean-Claude. A reprodução: elementos para uma teoria do sistema de ensino. Trad. Reynaldo Bairão. Petrópolis: Vozes, 2008.

BRASIL. Constituição da República Federativa do Brasil. Brasília (DF): Senado Federal, Centro Gráfico, 1988.

BRASIL. Emenda Constitucional n. 955/16. Diário Oficial da União. Brasília (DF), Seção 01, p. 02, 16 dez. 2016.

BRASIL. Lei n. 11.645/08. Diário Oficial da União. Brasília (DF), Seção 01, p. 01, 11 mar. 2008. CALLAI, Helena Copetti. Aprendendo a ler o mundo: a geografia nos anos iniciais do ensino fundamental. Cadernos Cedes, Campinas, v. 25, n. 66, p. 227-247, maio/ago. 2005.

CAMARGO, Dulce Maria Pompêo de; ZAMBONI, Ernesta. A criança, novos tempos, novos espaços: a história e a geografia na escola. Em Aberto, Brasília, a. 07, n. 37, p. 25-30, jan./ mar. 1988. 
CAMBI, Franco. História da pedagogia. Trad. Álvaro Lorencini. São Paulo: UNESP, 1999. CARDOSO, Frederico Assis. 0 que fizeram (e o que fizemos) de nós? Estudo de caso das trajetórias escolares de alunos/as do Ciclo Básico de Alfabetização (CBA) em Minas Gerais. 2013. 262 f. Tese (Doutorado em Educação) - Faculdade de Educação, Universidade Federal de Minas Gerais, Belo Horizonte.

CARVALHO, Marília Pinto de. No coração da sala de aula: gênero e trabalho docente nas séries iniciais. São Paulo: Xamã, 1999.

CHARLOT, Bernard. Da relação com o saber: elementos para uma teoria. 1. reimp. Trad. Bruno Magne. Porto Alegre: Artes Médicas, 2007.

CONTRERAS, José Domingo. A autonomia de professores. Trad. Sandra T. Valenzuela. São Paulo: Cortez, 2002.

COSTA, Marisa Vorraber. Pesquisa-ação, pesquisa participativa e política cultural da identidade. In: COSTA, Marisa Vorraber (Org). Caminhos investigativos II: outros modos de pensar e fazer pesquisa em educação. Rio de Janeiro: Lamparina Editora, 2007, p. 91-115.

DELAMONT, Sara. Interacção na sala de aula. Lisboa: Livros Horizonte, 1987.

DUBAR, Claude. A socialização: construção das identidades sociais e profissionais. Trad. Andréa S. M. da Silva. São Paulo: Martins Fontes, 2005.

DURKHEIM, Émile. A educação, sua natureza e seu papel. In: DURKHEIM, Émile. Educação e sociologia. Trad. Stephania Matousek. Petrópolis: Vozes, 2011, p. 43-73.

FORQUIN, Jean-Claude. Introdução: currículo e cultura. In: FORQUIN, Jean-Claude. Escola e cultura: as bases sociais e epistemológicas do conhecimento escolar. Trad. Guacira Lopes Louro. Porto Alegre: Artes Médicas, 1993, p. 09-26.

FREIRE, Paulo. A importância do ato de ler: em três artigos que se completam. 51. ed. São Paulo: Cortez, 2011.

GOETHE, Joham Wolfgang von. Os anos de aprendizado de Wilhelm Meister. Trad. Nicolino Simone Neto. São Paulo: Ensaio, 1994.

HOUAISS, Antônio; VILLAR, Mauro de Salles. Dicionário Houaiss da língua portuguesa. 1. ed. Rio de Janeiro: Objetiva, 2001.

LAHIRE, Bernard. Retratos sociológicos: disposições e variações. Trad. Patrícia C. R. Reuillard, Didier Martin. Porto Alegre: Artmed, 2004. 
LIBÂNEO, José Carlos. Produção de saberes na escola: suspeitas e apostas. In: CANDAU (Org). Didática, currículo e saberes escolares. 2. ed. Rio de Janeiro: DP\&A, 2002, p. 11-45. MASSCHELEIN, Jan; SIMONS, Maarten. O que é escolar? In: MASSCHELEIN, Jan; SIMONS, Maarten. Em defesa da escola: uma questão pública. Trad. Cristina Antunes. Belo Horizonte: Autêntica, 2013, p. 25-29.

MCLAREN, Peter. Rituais na escola: em direção a uma economia política de símbolos e gestos na educação. Trad. Juracy C. Marques; Ângela M. B. Biaggio. Petrópolis: Vozes, 1991.

MELLOUKI, M'hammed; GAUTHIER, Clermont. O professor e seu mandato de mediador, herdeiro, intérprete e crítico. Trad. Alain François. Educação \& Sociedade, Campinas, v. 25, n. 87, p. 537-571, maio/ago. 2004.

MILLS, Charles Wright. A imaginação sociológica. 2. ed. Trad. Waltensir Dutra. Rio de Janeiro: Zahar Editores, 1969.

MOLÉNAT, Xavier (Coord). La sociologie: histoire, idées, courants. Auxerre: Sciences Humaines Éditions, 2009.

MOREIRA, Antônio Flávio Barbosa (Org). Currículo: questões atuais. Campinas: Papirus, 1997.

NOGUEIRA, Maria Alice. Família e escola na contemporaneidade: os meandros de uma relação. Educação \& Realidade, Porto Alegre, v. 02, n. 31, p. 155-170, jul./dez. 2006.

NÓVOA, António (Org). Profissão professor. 2. ed. Porto: Porto Editora, 1999.

PIMENTA, Selma Garrido. (Org). Saberes pedagógicos e atividade docente. São Paulo: Cortez, 1999.

PIMENTA, Selma Garrido; GHEDIN, Evandro (Orgs). Professor reflexivo no Brasil: gênese e crítica de um conceito. 5. ed. São Paulo: Cortez, 2008.

POPKEWITZ, Thomas S.; PEREYRA, Miguel A. Práticas de reforma na formação de professores em oito países: esboço de uma problemática. In: NÓVOA, António; POPKEWITZ, Thomas S. (Orgs). Reformas educativas e formação de Professores. Lisboa: Educa, 1992, p. 11-40.

QUINO, Joaquín Salvador Lavado. Toda Mafalda: da primeira à última tira. Martins Fontes: Rio de Janeiro, 2002. 
RESENDE, Tânia de Freitas. No interior da "caixa preta": um estudo sociológico das interações em sala de aula. In: Associação Nacional de Pós-Graduação e Pesquisa em Educação - ANPEd: Sociedade, Democracia e Educação: Qual Universidade?, 27ª. Reunião Anual, 2004, Caxambu. Anais... Rio de Janeiro: ANPEd, 2004.

RESENDE, Tânia de Freitas; CANAAN, Mariana Gadoni; REIS, Laís da Silva; OLIVEIRA, Roberta Alves de; SOUZA, Tereza Cristina Starling de. Dever de Casa e Relação com as Famílias na Escola de Tempo Integral. Educação \& Realidade, Porto Alegre, v. 43, n. 2, p. 435-456, abr./jun. 2018.

SACRISTÁN, José Gimeno. O currículo: uma reflexão sobre a prática. 3. reimp. Trad. Ernani F. da Fonseca Rosa. Porto Alegre: Artmed, 2008.

SCHÖN, Donald A. Educando o profissional reflexivo: um novo design para o ensino e a aprendizagem. Trad. Roberto Cataldo Costa. Porto Alegre: Artmed, 2008.

SIROTA, Régine. A escola primária no cotidiano. Trad. Patrícia Chittoni Ramos. Porto Alegre: Artes Médicas, 1994.

SOUZA-E-SILVA, M. Cecília Pérez; FAÏTA, Daniel (Orgs). Linguagem e Trabalho: construções de objetos de análise no Brasil e na França. Trad. Inês Polegatto, Décio Rocha. São Paulo: Cortez, 2002.

TARDIF, Maurice. Saberes profissionais dos professores e conhecimentos universitários: elementos para uma epistemologia da prática profissional e suas consequências em relação à formação para o magistério. Revista Brasileira de Educação, Rio de Janeiro, n. 13, p. 05-24, jan./abr. 2000.

TARDIF, Maurice; LESSARD, Claude. 0 ofício de professor: história, perspectivas e desafios internacionais. 6. ed. Trad. Lucy Magalhães. Petrópolis: Vozes, 2014a.

O trabalho docente: elementos para uma teoria da docência como profissão de interações humanas. 9. ed. 1. reimp. Trad. João Batista Kreuc. Petrópolis: Vozes, 2014b.

TARDIFF, Maurice. O saber dos professores em sua formação. In: TARDIFF, Maurice. Saberes docentes e formação profissional. 17. ed. Trad. Francisco Pereira. Petrópolis: Vozes, 2014, p. 225-276.

VIANA, Gabriel Menezes. Construções de relações teoria-prática na formação de professores de ciências e biologia. 2014. 319 f. Tese (Doutorado em Educação) - Faculdade de Educação, Universidade Federal de Minas Gerais, Belo Horizonte, 2014. 
VINCENT, Guy; LAHIRE, Bernard; THIN, Daniel. Sobre a história e a teoria da forma escolar. Trad. Diana G. Vidal. Educação em Revista, Belo Horizonte, n. 33, p. 07-47, jun. 2001. WILLIAMS, Raymond. The long revolution. Londres: Peguin Books, 1961.

ZAMBONI, Ernesta; FONSECA, Selva Guimarães. Contribuições da literatura infantil para a aprendizagem de noções do tempo histórico: leituras e indagações. Cadernos CEDES. Campinas, v. 30, n. 82, p. 339-353, set./dez. 2010.

ZARANKIN, Andrés. Paredes que domesticam: arqueologia da arquitetura escolar capitalista. O caso de Buenos Aires. 2001. 255 f. Tese (Doutorado em História) - Instituto de Ciências Humanas, Universidade Estadual de Campinas, Campinas, 2001.

\section{FILMES}

Ao mestre, com carinho. Direção: James Clavell. Reino Unido, 1967. 1. DVD Disc (105min), color. Produção: Columbia Pictures. Drama. [Título original: To sir, with love].

Escritores da liberdade. Direção: Richard LaGravenese. Estados Unidos da América, 2007. 1 DVD Disc (122min), color. Produção: Double Feature Films, Jersey Films, Paramount Pictures. Drama. [Título original: Freedom Writers].

Meu mestre, minha vida. Direção: John G. Avildsen. Estados Unidos da América, 1989. 1 DVD Disc (109min), color. Produção: Warner Brothers. Drama. [Título original: Lean on Me].

Mr. Holland: adorável professor. Direção: Stephen Herek. Estados Unidos da América, 1995. 1 DVD Disc (142min), color. Produção: Buena Vista, Charlie Mopic Company, Interscope Communications. Drama. [Título original: Mr. Holland's Opus].

O sorriso de Mona Lisa. Direção: Mike Newell. Estados Unidos da América, 2003. 1 DVD Disc (119min), color. Produção: Columbia Pictures, Red Om Films, Revolution Studios, Shoelace Productions. Drama. [Título original: Mona Lisa Smile].

Sociedade dos Poetas Mortos. Direção: Peter Weir. Estados Unidos da América, 1989. 1 DVD Disc (128min), color. Produção: Buena Vista, Silver Screen Partners IV, Touchstone Pictures. Drama. [Título original: Dead Poets Society].

Um tira no jardim de infância. Direção: Ivan Reitman. Estados Unidos da América, 1990. 1 DVD Disc (111min), color. Produção: Universal. Comédia. [Título original: Kindergarten Cop]. 